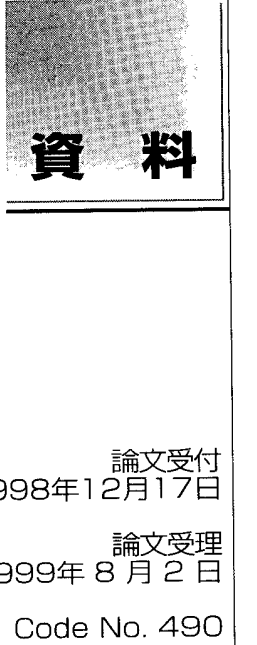

\section{近畿地区の放射線治療技師の実態アンケート調查 一放射線技師の労働環境についてー}

\author{
松本光弘 $\cdot$ 大島徹也 ${ }^{1)} \cdot$ 小味昌憲 ${ }^{2)} \cdot$ 谷 正司 $^{3)} \cdot$ 黒田啓史 ${ }^{4)}$ \\ 小山裕之 ${ }^{5)} \cdot$ 高橋博史 $^{6)} \cdot$ 小田雅彦 ${ }^{7)} \cdot$ 岡山貴宣 $^{8)}$ \\ 大阪大学医学部附属病院放射線部 \\ 1 ) 大阪府立病院放射線治療科 \\ 2)市立泉佐野病院放射線部 \\ 3)大阪府立母子保健総合医療センタ一放射線科 \\ 4)大阪市立総合医療センタ一中央放射線部 \\ 5)市立福知山市民病院放射線科 \\ 6)星ヶ丘厚生年金病院放射線部 \\ 7)兵庫医科大学附属病院中央放射線部 \\ 8)神戸大学医学部附属病院放射線部
}

\section{1. はじめに}

昨今，放射線診療業務は医学・医療の進歩に相まっ て多角細分化の傾向にあり，それに伴い放射線技師の 専門性が要求されている．放射線治療も同様であり， 以前はコバルトやリニアックなどの外部照射単独の業
務従事だったのが，最近では外部照射装置の複雑化， 照射技術の高精度化，治療計画の高度化(三次元線量 分布作成等)，腔内組織内照射や集光照射の普及に伴 う治療計画，およびそれらの照射業務の煩雑化，また 骨髄バンクの発足による全身照射の増加など，技師の

\title{
Questionnaire Survey of Working Conditions of Radiotherapy Technologists in the Kinki Region
}

\section{MITSUHIRO MATSUMOTO • TETSUYA OHSHIMA') • MASANORI KOMI') ' SHOJI TANI ${ }^{3)}$ • KEIJI KURODA4), HIROYUKI KOYAMA ${ }^{5)}$ - HIROSHI TAKAHASHI ${ }^{6)} \cdot$ MASAHIKO ODA $^{7)}$ and TAKANOBU OKAYAMA ${ }^{8)}$}

Department of Radiology, Osaka University Hospital

1) Department of Radiation Oncology, Osaka Prefectural General Hospital

2)Izumisano Municipal Hospital, Department of Radiology

3) Department of Radiology. Osaka Medical Center and Research Institute for Maternal and Child Health

4) Department of Radiology, Osaka City General Hospital

5) Department of Radiology. Fukuchiyama City Hospital

6) Department of Radiology. Hoshigaoka Koseinenkin Hospital

7)Department of Clinical Radiology. Hyogo College of Medicine

8)Division of Radiological Technology, Kobe University Hospital

Received Dec. 17, 1998; Revision accepted Aug. 19, 1999; Code No. 490

\section{Stummary}

This article reports the results of an April 1998 survey conducted among radiotherapy technologists in the Kinki region in order to investigate their working conditions at that time. According to the results, 26.6 $\%$ of the radiotherapy technologists were working exclusively with a specific modality, $37 \%$ worked concurrently with two modalities, and $36.4 \%$ worked with all modalities on shift rotation. Many of the respondents reported working alone. The number of radiotherapy technologists working exclusively with a specific modality increased in proportion to the number of beds, while that of radiotherapy technologists working concurrently with other modalities decreased in inverse proportion to the number of beds, and that of radiotherapy technologists on shift rotation remained at a constant level. Most of the radiotherapy technologists started work between 8:30 and 9:00 and finished at 17:00. Overtime work averaged one hour.

Key words: Questionnaire, Working conditions, Radiotherapy technologist

別刷資料請求先：于565-0871 吹田市山田丘2-15

大阪大学医学部附属病院 放射線部 松本光弘 宛 
業務関与が拡大してきた。ささらにQA，QCの普及に伴 い,これらの作業を診療時間外(残業)で行っている施 設が多いとの指摘もある。

しかしながら，技師定員は旧来と変化なく，多くの 施設が少数名の技師で多くのモダリティの業務に従事 しているのが現状であろうと思われる.

そこで，実際にどのような労働環境の中で放射線技 師が従事しているのかを調査し, 現状を整理すること で各施設でのマンパワーの検証に役立てればと考え, 本調査を実施した。

1998年 4 月に近畿地区の放射線治療施設に対して, 放射線治療に携わる技師の労働環境についてアンケー 卜調查を実施した。過去にも治療施設に関する実態調 査報告1 6) はなされているが, われわれは治療担当技 師の労働環境について解析し, 若干の所見を得たので 報告する.

\section{2. 方 法}

アンケート方法は，放射線治療かたろう会(以下， かたろう会)の全面協力のもと, 放射線治療施設担当 者宛に，直接FAXにて質問用紙を送付し，回答もFAX あるいは電子メールにて回答をいただく方法をとった ため回収率は $100 \%$ であった。

Fig.1にそのアンケート用紙の質問表(拔粋)を示す.

\section{3. 結果および考察}

\section{3-1 施設と技師の業務体系について}

かたろう会参加82施設のうち, 放射線治療実施施設 が78, その内訳はリニアック・マイクロトロン：71施 設(コバルト併設含む)，コバルト単独：7 施設であ り, 平成 10 年 4 月時点で設置中の施設が 2 , 未実施施 設 2 であった。

アンケート結果より, 治療実施78施設の公称病床数 (以下, ベッド数)の総数は 45,625 床で 1 施設平均 585 床(最大 1980 最小 40 )，技師の総数は 1,452 人で 1 施 設平均 18.5 人 (最大 48 最小 3 ), 治療担当技師の総数 は 302 人で 1 施設平均 3.9 人 (最大 10 最小 1 )であっ た.ただし，治療技師総数は日常的にこれだけのマン パワーで治療が行われている訳ではなく, あくまでも 治療部門に在籍している技師数である.

さらに技師の業務体系別(専任・兼任・ローテーシ ヨン)技師数をFig.2aに示す。ここで専任技師とは放射 線治療に専従で業務している技師，兼任技師とは放射 線治療と他の部門(たとえば，一般撮影やCT，MRIな ど)と兼務している技師，ローテーション技師とはあ る一定の期間で複数の部門を順番に移動している技師 と定義した。

専任治療技師数は 80 人で 1 施設平均 1.0 人(最大 4
最小 1 ), 兼任技師数は 112 人で 1 施設平均 2.7 人 (最大 9 最小 1$)$, ローテーション技師数は 110 人で 1 施設 平均 2.6 人(最大9〜最小 1 )であった。このデー夕も先 程と同じように日常的なマンパワーではない。これら の詳細な内訳をFig.2bに示す．これより，どの業務体 系でも 1 人勤務の施設数が最も多かった.

つぎに施設の規模を示す指標の一つであるベッド数 ごとに解析したものをFig.3に示す. Fig.3aはべッド数 に対する技師数を示す. 図の上段の分布はその施設の 技師長を含めた技師総数を表し，下段の分布は治療所 属技師数を示す. 図より治療技師の人員は施設の技師 総数やベッド数にあまり関係なく配置されていた。さ らにFig.3bでは, 治療担当技師を体系別に分けて評価 した．図より治療担当技師の総数はべッド数 $300 ５ 00$ 床と 1,000 床以上にピークがあった。 また，専任技師 数はべッド数の上昇とともに増加している，一方，兼 任技師はベッド数300～500床挹よび1,000床以上の施 設に多く, 全体の傾向としては専任技師の逆の増減で あった。 またローテーション技師はベッド数に関係な くほぼ定の割合で人員配置されていた。

一方, ベッド数 $500 \sim 1,000$ 床の施設では, 施設規模 の割に治療担当技師数が少なかったが，500床以下の 施設に比べ専任技師の割合が多いのが特徴であった。

\section{3-2 兼任技師とローテーション技師の勤務形態につ いて}

兼任技師とローテーション技師の勤務形態をFig.4 に示す. Fig.4aは兼任技師の兼任割合を示す．1 日の うち午前あるいは午後に治療部門で勤務しているのが 33\%(13施設), 週のうち 1 3 日勤枒が39\%(16施 設), 月のうち 1 - 週勤務が $28 \%(11$ 施設)であり, ほ ほ均等であった．Fig.4bはローテーション技師のロー テート割合を示す。週のうち数日勤務が14\%(5施 設), 月のうち数週勤務が $19 \%$ (7施設), 年のうち数力 月勤務が一番多く $40 \%$ (15施設), 年次交代勤務が $27 \%$ (10施設)であった．特に回答数が多かったのが， 1 週 間交代勤務 (5 施設), 2 力月交代勤務 (4 施設) と 6 力 月交代勤務 (6 施設), 1 年交代勤務 (7 施設)であった。

\section{3-3 治療専任技師の専任程度について}

40施設(約50\%)に80名の放射線治療専任技師が在籍 し, このうちの10施設は何らかの形で専任技師の配置 替えを行っている. その在任期間の多くは $2 \sim 4$ 年で あるとの回答であった.

\section{3-4 実際の業務体系の分類について}

実際の施設ではどのような業務体系の組み合わせで 業務されているかを解析した結果をFig.5に示す. 回 
放射線治療かたろう会 第 1 回アンケート調查用紙

問1 所属施設の正式名称 (

所属部所の正式名称

閥 2 施䩔の公称ベッド数

床

問 3 技師総数（技師長含む）

) 名

問 4 治療勤務総技師数（兼任，ローテーション含む）

) 名

間 5 治療勤稀技師の内の，尃任技師数

)名

問 6 治㙩黝邪技師の内の，兼任技師数

)名.

問 7 治療勒㢦技師の内の，ローテーション技師数

名

問 8 兼任技師の治葲業務割合柱，

$$
\text { （）時間/日，(）日/遇，（）遇/月，（）月/年 }
$$

閥 9 ローテーション技師のローテーション期間は,

$$
\text { （）日/週，(）遇/月，（）月/年，（）年 }
$$

問10 専任技師のローテーションの有無，〈ローテーションしている，していない)

1. ローテーションしている堨合，そのローテーション周期は.

$$
\text { （）週，(）月，(）年 }
$$

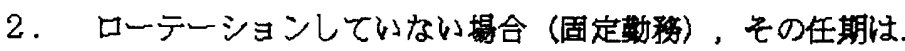

$$
\text { ((）年，特に決まっていない，不明) }
$$

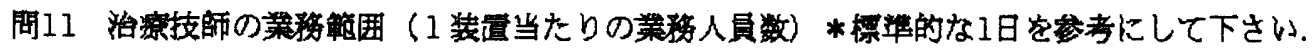

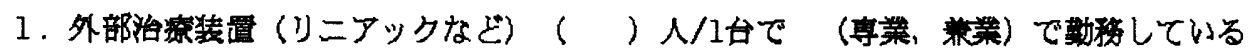

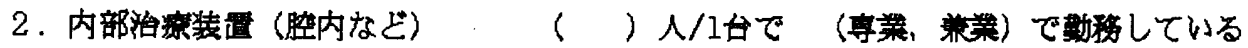

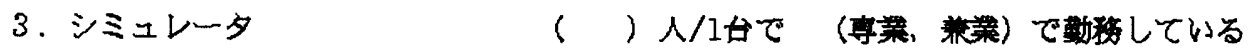

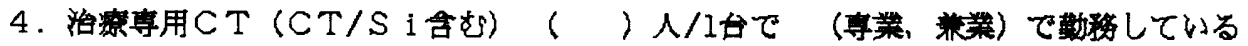

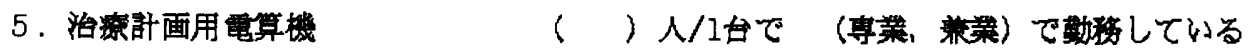

6. 温热治寮

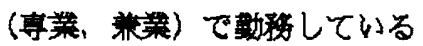

7. その他

問12 治寮技師の平均的業雅時間

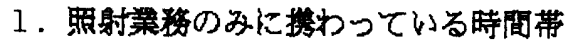

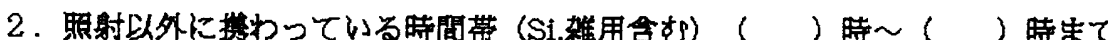

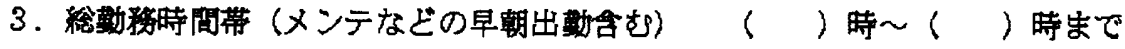

4. 平均残暂時間数

( ) 時間

5. 大体，毎日(）時には退出できる.

間13リニアックなどの線量校正について（1装量当たり）

1. 校正頻度（）回/淍，（）回/月，（）回/年

2. 作業時間帯 ( ) 時〜（）時まで

3. 作業人員(）人

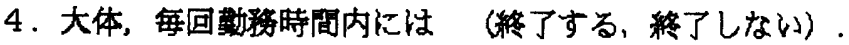

Fig. 1 Questionnaire sheet. 


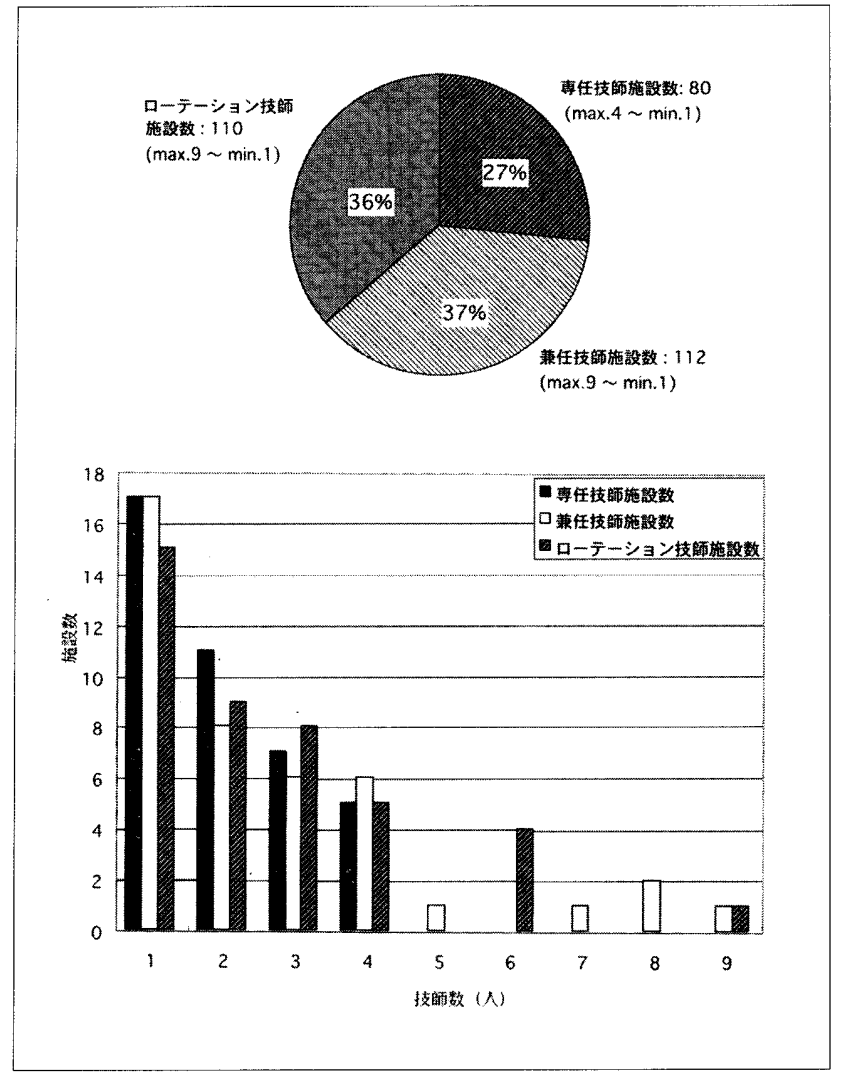

Fig. 2 (a) Proportion of radiotherapy technologists categorized according to working conditions.

a

(b) Number of radiotherapy technologists and institutions.

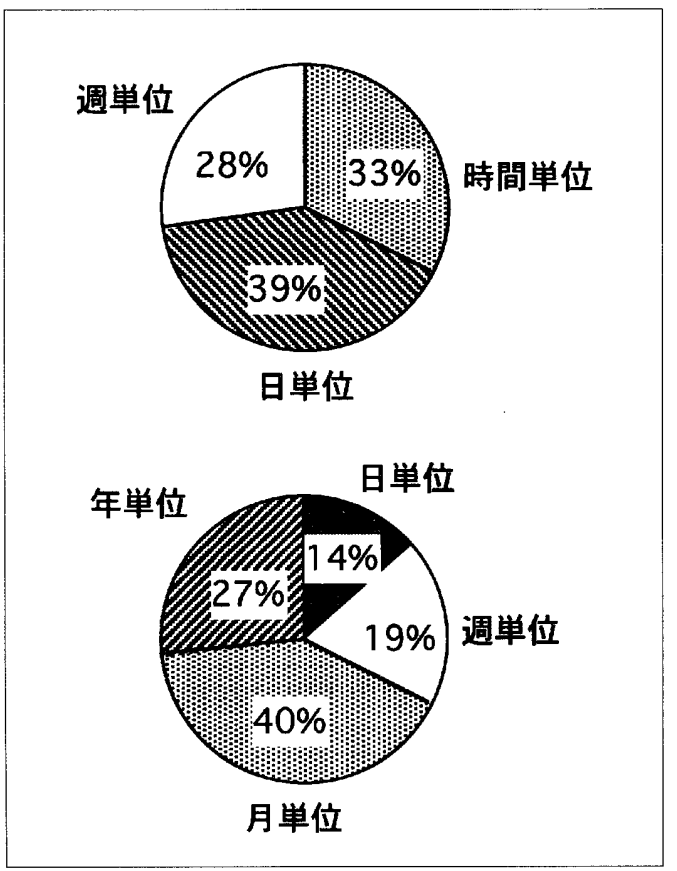

Fig. 4 Working conditions of radiotherapy technologists concurrently working with other modalities and radiotherapy technologists working on shift rotation.
(a) Duration of concurrent work with other modalities.

(b) Time on shift rotation.

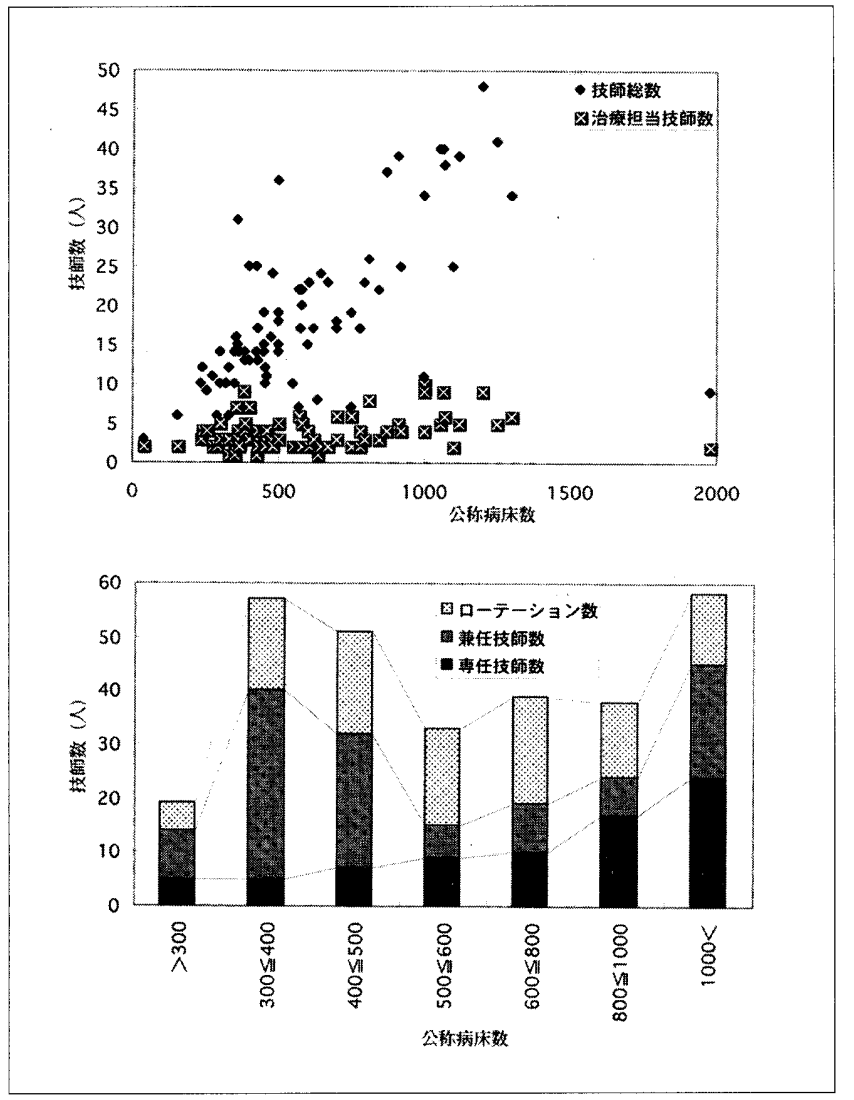

Fig. 3 Number of radiotherapy technologists cat- a egorized according to number of beds.

(a) Ratio of radiotherapy technologists to the total number of radiological technologists.

(b) Working categories of radiotherapy technologists.

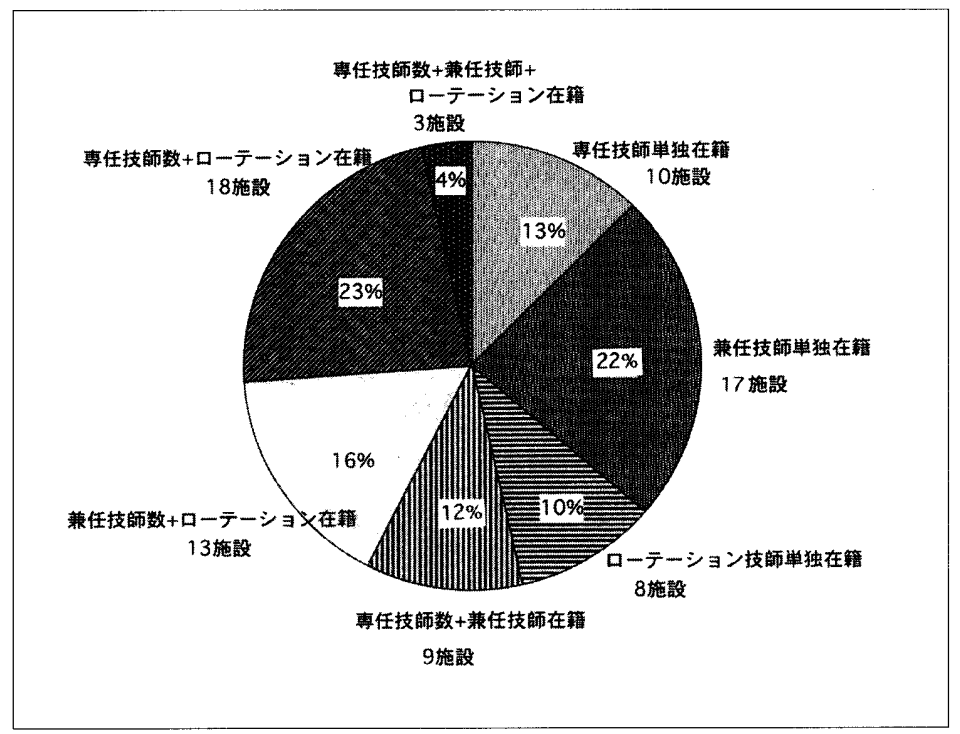

Fig. 5 Number of institutions with combined working conditions. 
答数は77施設であった。

専任技師のみで治療が行われている施設は10施設で あり，兼任技師のみで治療が行われているのは17施 設，ローデーション技師のみで治療が行われているの は8 施設であり，そのほか，罒に示すような組み合わ せで業務が行われている。図からも明かなように突出 したカテゴリはなく，最も多いものでも専任技師と口

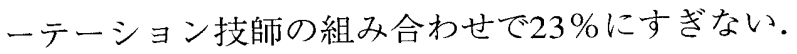

\section{3-5 治療装置(外部照射) 1 台当たりの業務人員につ} いて

治療担当技師の総数は 302 人で， 1 施設平均にする と約 4 人のマンパワーがある計算になる。しかし，こ の数值はあくまで治療部門に在籍している技師数であ

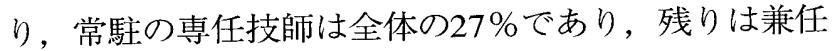
技師，ローテーション技師が占めている. そのような 勤務環境で実際の外部照射装置(リニアックなど) 1 台 当たりに何人のマンパワーがあるのか検証する必要が ある。その結果をFig.6に示す。

Fig.6aは治療装置 1 台当たりの担当技師数を示す. 図より担当技師数が 3 名の施設は $4 \%$ で 3 施設, 2 名 は $48 \%$ で37施設，1.5名は $8 \%$ で 6 施設，1 名は $40 \%$
で31施設であった。このうち 1.5 名の施設では半日が 1 人勤務になると思われるため，概略で 1 人勤務の施設 割合は約 $50 \%$ と半数となった。

つぎに施設のベッド数で解析した結果をFig.6bに示 す. 図から明かなように, 勤務人員とベッド数の相関 はあまりない。

さらにこれを，施設の技師総数で解析した結果を Fig.6cに示す.この結果も先ほどのベッド数と同じ で，施設の技師総数との相関はあまりなかった。たた し, ベッド数で700床以上, 技師総数で30名以上の施 設では概略 2 人勤務の率は高い. それ以外の施設で は, ベッド数や技師の総数とは関係なく, その施設自 体の都合あるいは組織上の問題で 1 人勤務であった り，2人勤務であったりしているのではないだろう 加.

\section{3-6 技師の業務時間と平均残業時間について}

日常的な 1 日の平均的な照射開始時刻，照射終了時 刻，勤務開始時刻，勤務終了時刻，退出時刻をFig.7 に示す。

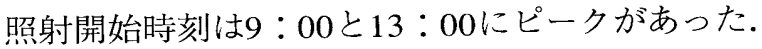
これは照射業務が午前のみ $(29.5 \%, 23$ 施設 $)$ と午後の
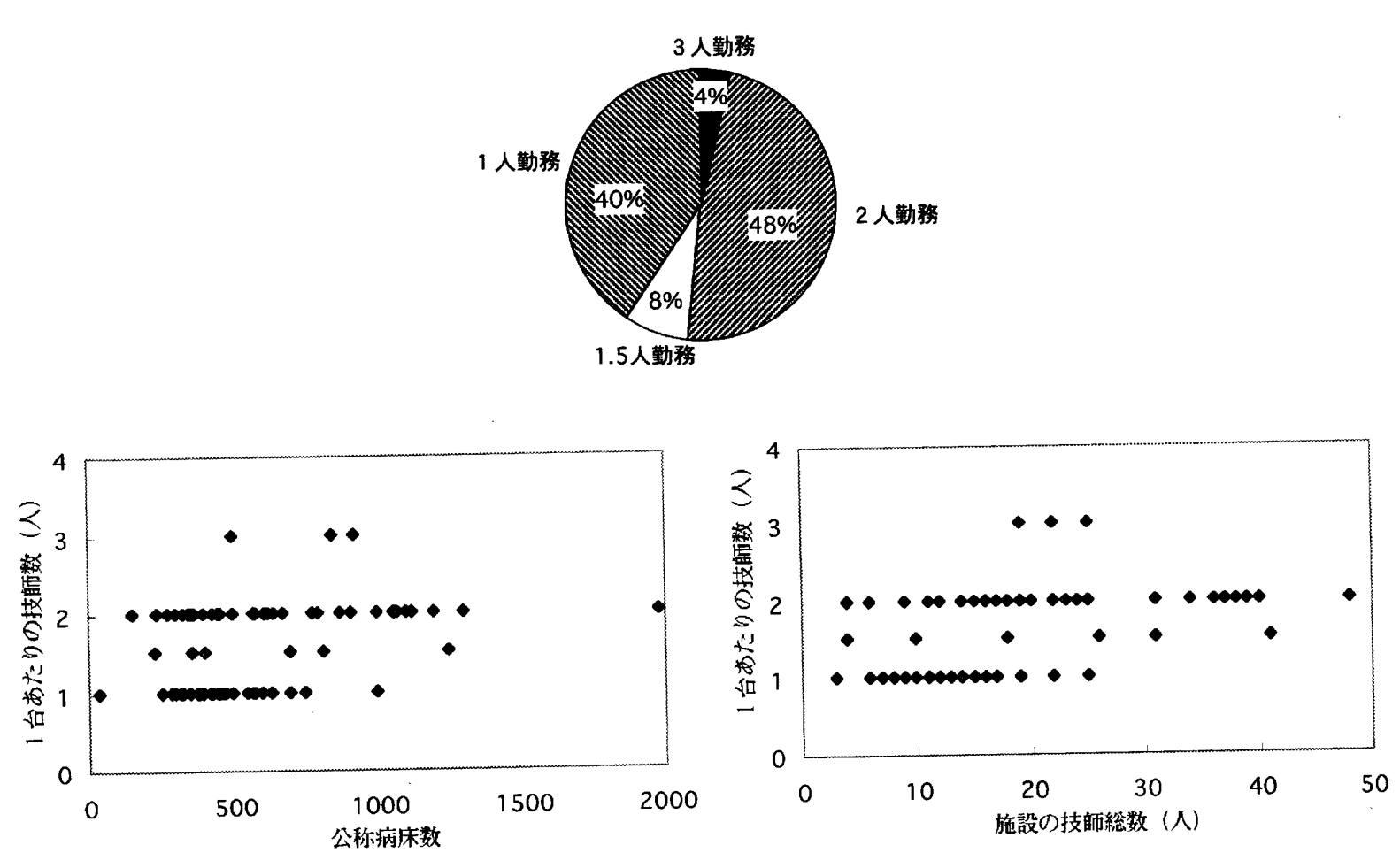

Fig. 6 Number of radiotherapy technologists per treatment unit.

(a) Breakdown.

(b) Ratio of radiotherapy technologists to number of beds.

(c) Ratio of radiotherapy technologists to radiological technologists and technicians to the total number of radiological technologists and technicians per unit. 
み(18\%，14施設)，および全日業務 $(52.5 \% ， 41$ 施設) の施設に分かれていることを示す。このことは照射の

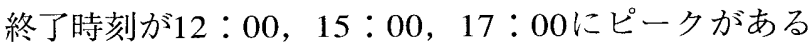
ことや，勤務開始時刻が8：00台と13：00にピークが あることからでも分かる。多くの施設が8：30あるい は9：00始まりであるが，約 8\%の施設では7：30勤務

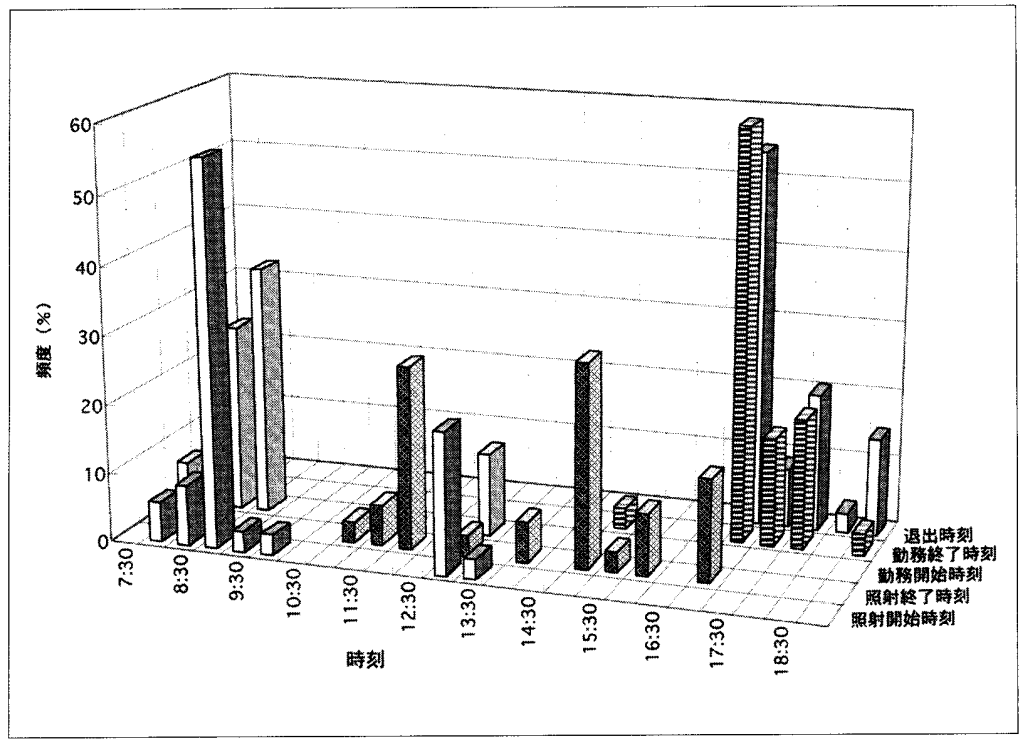

Fig. 7 Working hours of radiotherapy technicians.

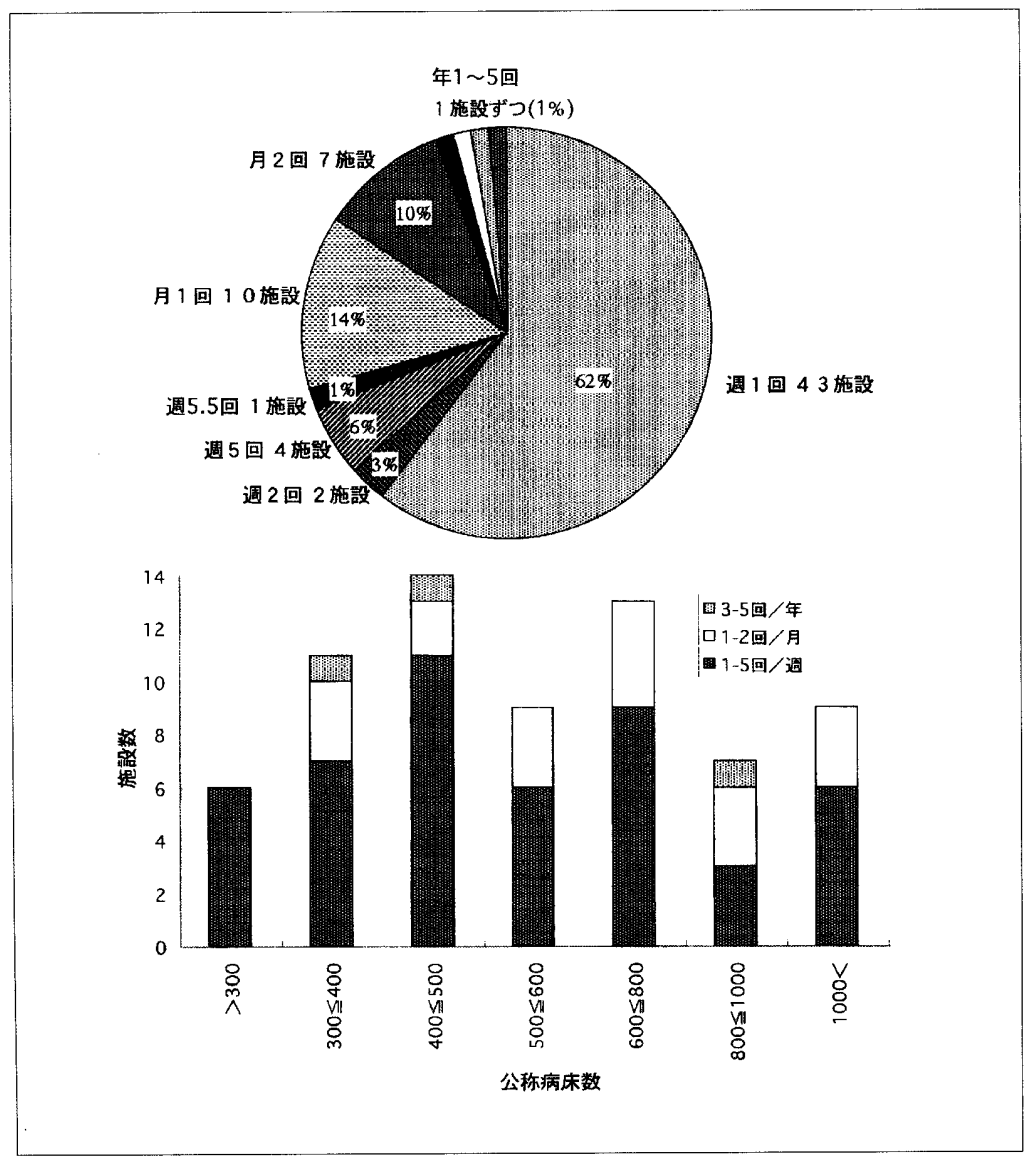

Fig. 8 Dose calibration frequencies.

(a) Breakdown.

(b) Number of beds and institutions.
開始の8：00照射開始であった。また勤務終了時刻は ほとんどが17：00であるが，約30\%の施設では17： 30 18：00の終了時刻で，退出時刻も約50\%近くが $18 ： 00$ 19:00であった。

つぎに，平均残業時間はおおむね約 1 時間であり， 1 時間以上の残業をしている施設は37\%(29施設)であ つた (有効回答数 43 ).

\section{3-7 治療装置の線量校正について}

治療装置 (コバルト装置除く)の校正 深による線量校正の頻度と作業人員と 作業時間についての結果をFig.8に示 す. Fig.8aは線量校正の校正頻度の割合 を示す。最も校正頻度が高かったの は，週に 1 回の校正で $62 \%(43$ 施設)で あった。また週に 2 回や毎日校正して いると回答された施設が 7 施設であっ た。その反面，月に2 回は10\%(7 施 設)，月に1回は $14 \%(10$ 施設)あり，さ らに年に $3 ， 4 ， 5$ 回がそれぞれ 1 施設ず つであった。

つぎに，この校正頻度を施設のベッ ド数で解析したものをFig.8bに示す. べ ッド数 300 床以下では技師数も少ないと 思われるが，すべての施設で週 1 回の校 正頻度であったまた，400床以上の施 設ではほほ均等な割合で月に1〜2回の 校正頻度であった。さらに年に3〜5回 の施設は300～500床および800～1000 床と比較的大きな施設でみられた。

線量校正の作業開始時間と校正期間 の関係をFig.9に示す. 有効回答数は64 であった，校正期間が週に5回（毎日） はすべて就業前に行われていた。その 他の場合はほとんどが午後の治療終了 後に行われている。また，「校正作業は 勤務時間带に終了しますか」との質問に 対する回答は，「終了する」が76\%(54施 設)，「終了しない」が24\%(17施設)であ った，有効回答数は71であった。

\section{4. 結 語}

アンケートの集計結果ならびにデータ 解析の結果を以下にまとめる。

(1)平成10年 4 月時点での, かたろう会 参加施設数は82, そのうち治療実施施 設は78であった。その後新規に 2 施設 が診療を開始したため, 平成10年度で 


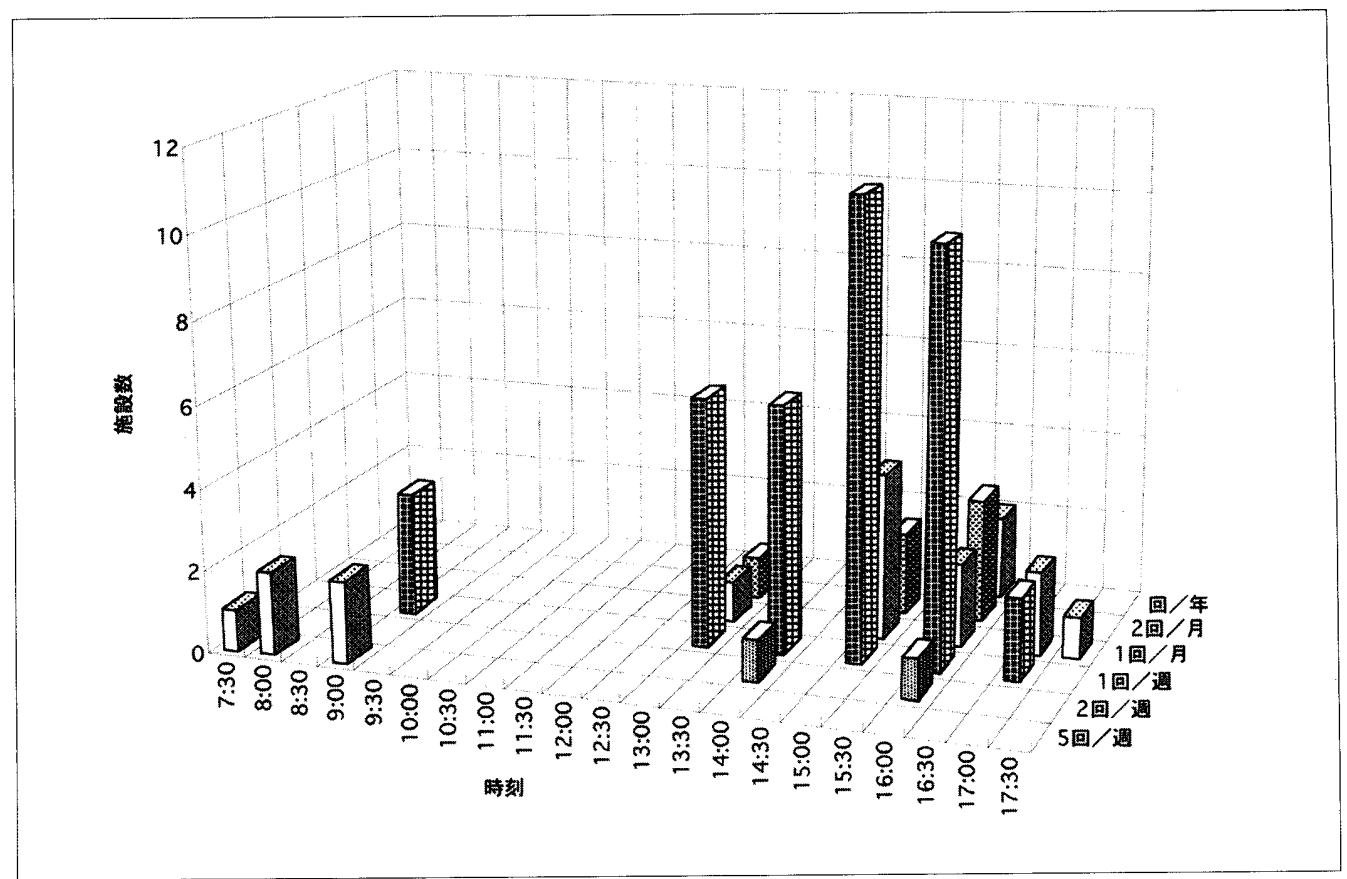

Fig. 9 Starting times of dose calibration categorized by frequency.

は治療実施施設は80となっている。

(2) 治療施設の内訳は, リニアック・マイクロトロ ン：71施設(コバルト併設含む)，コバルト単独： 7施設，合計78施設であった。

（3）治療技師の業務体系は，専任技師：26.6\%(80 人，40施設)，兼任技師： $37 \%(112$ 人，42施 設)，ローテーション技師： $36.4 \%$ (110人，42施 設)であり，どの体系も 1 人勤務が多数を占めて いた。

(4) 治療担当技師の総数は, 所属施設の技師総数や施 設のベッド数に相関せず，ある一定範囲の人員配 置であった。

(5) 専任技師数はほぼベッド数に比例し，兼任技師数 はベッド数に反比例し，ローテーション技師数は ベッド数に関係なく一定であった.

(6) 兼任技師の兼任割合は，1 日のうちの数時間，1 週の内の数日, 1 力月のうちの数週の 3 通りでほ ぼ均等割合であった。

（7）ローテーション技師のローテート割合は，1 年の うち, 数力月は最も多く, 次いで 1 年交代のイン ターバルであった。

(8) 専任, 兼任, ローテーションの組み合わせで最も 多かったのは，専任十ローテーションで23\%， 次いで専任のみで $22 \%$ あ゙あり，大きく突出した カテゴリはなかった。

(10) 治療装置 1 台当たりの業務人員は, 概略施設ベッ
ド数や技師総数に関係なく，配置されている。 た だし，ベッド数で700床以上や技師総数 30 名以上 の大規模施設ではほぼ 1 台当たり 2 名の技師が配 置されている.

(11) 技師の業務時間は，概略 8：30から 9：00開始で $17 ： 00$ 終了であったが, 一部の施設では7 : 30開 始であったり，18：00終了といったハードな施設 もあった。 また残業時間も平均 1 時間であった。

(12)リニアック等の線量校正の間隔は，62\%が週に 1 回のペースで行っていた。また週に 2 回や毎日の 施設もあり，これらを含めると週ごとに校正して いる施設は全体の 7 割であった. 残りの 3 割の施 設では月に2〜1回，年に5〜3回の割であった。 これらを施設のベッド数でみると, 週ごとはすべ ての区分, 月ごとも300床以下を除くすべての区 分，年ごとは300～500，800～1000床の中規模以 上の施設であったのが気にかかる点であった。

(13) 線量校正の作業時刻は，ほとんどが通常の治療業 務終了後に行っているが，毎日あるいは週 1 回の 施設では，治療開始前に校正を行っている施設も あった。

\section{謝 辞}

本アンケート調査にご協力いただきました，放射線 治療かたろう会参加 82 施設の治療担当技師の皆様方に この場を㧍借りして御礼申し上げます。 


\section{参考文献}

1) 沢 佳延, 佐藤和久, 亀田順一, 他：栃木県に㧈ける放射 線治療の実態調查とトレーサビリテイ。日放技学誌，43 (4), 539, (1987).

2) 竹中栄一, 太田 宏, 飯沼 武, 他：治療技術評価委員会 報告一治療施設の実態調査について一，放射線治療システ 厶研究, suppl No.5, 11-17，(1988).

3）川越康充, 菊池利邦, 伊藤慎弥, 他：近畿地区に扮ける外 部照射法の実態調査一主として治療計画の利用に関して

一。昉技学誌，47(1)，28-35，(1991).
4）石川啓二，桜中秀樹，浅野茂夫，他：仙台地区で使用して いる線量測定器具の比較検討。日放技学誌，51(3)，347, (1995).

5）横山公一，桑原秋夫，遠藤裕二，他：東京地区に扔ける外 部放射線治療装置のX線校正点吸收線量の比較測定調查. 放射線医学物理，16(1)，9-17，(1996).

6) 平成8年度学術委員会 治療線量の実態調查班：治療線量の 実態調査 (高エネルギーX線測定)一訪問測定による吸収線 量の評価一。放技学誌，54(11)，1322-1335，(1998).

Fig.1アンケートの質問用紙.

Fig.2 (a) 治療技師の業務体系別割合

(b) 技師数と施設数.

Fig. 3 ベッド数別技師数.

(a) 総技師数と治療技師数

(b) 業務体系別技師数.

Fig.4兼任技師とローテーション技師の勤務形態。
(a) 兼任技師
(b)ローテーション技師.

Fig.5技師の業務体系の組み合わせ施設数。

Fig.6 治療装置 1 台当たりの担当技師数.
(a) 内訳
(b)ベッド数に対する担当技師数
(c) 技師総数に対する担当技師数.

Fig.7 業務時間带.

Fig.8線量校正の頻度.
(a) 内訳
(b)ベッド数別施設数

Fig.9＼cjkstart線量校正の頻度別作業開始時間. 